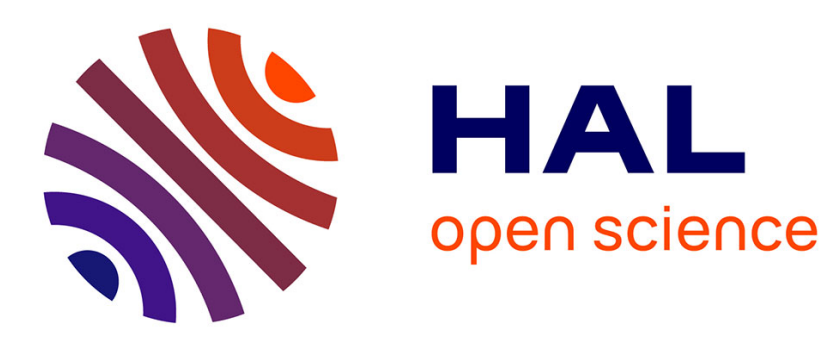

\title{
The European Union and Human Rights: Towards A Post-National Human Rights Institution?
}

\author{
Samantha Besson
}

\section{To cite this version:}

Samantha Besson. The European Union and Human Rights: Towards A Post-National Human Rights Institution?. Human Rights Law Review, 2006, 6 (2), pp.323-360. 10.1093/hrlr/ngl001 . hal-02516239

\author{
HAL Id: hal-02516239 \\ https://hal.science/hal-02516239
}

Submitted on 11 May 2020

HAL is a multi-disciplinary open access archive for the deposit and dissemination of scientific research documents, whether they are published or not. The documents may come from teaching and research institutions in France or abroad, or from public or private research centers.
L'archive ouverte pluridisciplinaire HAL, est destinée au dépôt et à la diffusion de documents scientifiques de niveau recherche, publiés ou non, émanant des établissements d'enseignement et de recherche français ou étrangers, des laboratoires publics ou privés. 
Human Rights Law Review 6:2 C The Author [2006]. Published by Oxford University Press. All rights reserved. For Permissions, please email: journals.permissions@ oxfordjournals.org doi:10.1093/hrlr/ngl001 Advance Access published on 22 July 2006

\title{
The European Union and Human Rights: Towards A Post-National Human Rights Institution?
}

\author{
Samantha Besson*
}

\begin{abstract}
There is growing evidence that the European Union (EU) is becoming more involved in human rights protection and has the capacity to turn into an unprecedented post-national human rights protection institution. Based on that evidence, this article suggests different arguments in favour of a further development in this direction. These arguments stem not only from a general global justice approach to post-national institutions' responsibilities, but also from the concept of human rights itself and the specific needs of human rights protection at the post-national level. The EU's institutional framework presents advantages that fit the general criteria of institutional design in the human rights context. Of course, many doubts and critiques may be raised against an entity which started primarily as a functional and economic institution, and important reforms, some of which are ventured in the present article, are still needed to get the EU closer to this institutional ideal. More generally, the article emphasises the unique example and precedent the EU may constitute for normative institutional thinking about global justice at the post-national level.
\end{abstract}

* PhD (Bern), Dr.iur. (Fribourg), M.Jur. (Oxon.), lic.iur. (Fribourg and Vienna). Professor of International Law and European Law, Law Faculty, University of Fribourg. This article was written within the framework of the Project for a European Philosophy of European Law funded by the Swiss National Science Foundation (http://fns.unifr.ch/peopel). I would like to thank Franziska Martinsen, MA (Berlin) for her research assistance on an early draft of the article. Many thanks are also due to two anonymous referees whose comments have helped me clarify the article. 


\section{Introduction}

Despite what some may argue, economic integration is to a large extent exhausted as a vision for further integration in the European Union $\left(\mathrm{EU}^{1}\right)^{2}{ }^{2}$ A new vision is yet to be found. Since 2000, human rights ${ }^{3}$ have become an increasingly important element of institutional activity and constitutional construction in Europe. ${ }^{4}$ Reinforced by the adoption of the EU Fundamental Rights Charter ('Charter') in 2000 and its constitutionalisation in the Treaty establishing a Constitution for Europe (TCE) in 2004, human rights now truly lie at the heart of the Union's values and objectives (see Articles I-2, I-3 and I-9, TCE). The prospects of enlargement have further contributed in the last few years to identifying national, regional and global threats to human rights and hence to conscientise the EU's vision of itself as a global entity, whose 'one boundary is democracy and human rights. ${ }^{5}$ True, the constitutionalisation process seems currently to have come to a halt, but this is likely to be only temporary. ${ }^{6}$ Moreover, even if it remains non-binding, it is unlikely that the Charter would be

1 In the present article, the terms 'European law' or 'EU law' refer to the law of the Treaties on the European Union, including the law of the European Community. Although in many cases, European law will in fact be EC law, I will refer for reasons of clarity to European or EU law in general. For the same reasons, I will often refer to the European Union to talk of what has now become the Union.

2 von Bogdandy, "The EU as a Human Rights Organisation?-Human Rights and the Core of the European Union', (2000) 37 Common Market Law Review 1307 at 1337.

3 In this article, I will use 'human rights' and 'fundamental rights' interchangeably, although international human rights are usually said to have a larger scope than national fundamental rights. Indeed, in the EU context, the distinctions between national and international human rights protection, on the one hand, and between Member States' constitutional fundamental rights traditions, EC fundamental rights qua general principles of EC law and the European Convention of Human Rights, on the other, have become moot. It is true that the distinction between human rights and fundamental rights is also often used to emphasise the legal nature of fundamental rights, and in particular to distinguish between moral human rights and constitutional fundamental rights. However, since human rights can be regarded as the most encompassing group, the concept will generally be used as a default concept.

4 See, for example, Lenaerts, 'Fundamental Rights in the European Union', (2000) 25 European Law Review 575; De Burca, 'Human Rights: The Charter and Beyond', Jean Monnet Working Paper 10/2001; Beaumont, 'Human Rights: Some Recent Developments and Their Impact on Convergence and Divergence of Law in Europe', in Beaumont, Lyons and Walker (eds), Convergence and Divergence in European Public Law (Oxford: Hart Publishing, 2002) 151; Kühling, 'Grundrechte', in von Bogdandy (ed.), Europäisches Verfassungsrecht, Theoretische und Dogmatische Grundzüge (Berlin: Springer, 2003) 583; Dutheil de la Rochère, 'The EU and the Individual: Fundamental Rights in the Draft Constitutional Treaty', (2004) 41 Common Market Law Review 345; Alston and de Schutter, 'Introduction: Addressing the Challenges Confronting the EU Fundamental Rights Agency', in Alston and de Schutter (eds), Monitoring Fundamental Rights in the EU, The Contribution of the Fundamental Rights Agency (Oxford: Hart Publishing, 2005) 1.

5 Declaration of the Laeken Council, available at: http://european-convention.eu.int/pdf/ LKNEN.pdf.

6 Declaration by the Heads of State or Government of the Member States of the European Union on the ratification of the Treaty establishing a Constitution for Europe-European Council, 16 and 17 June 2005. Available at: http://www.eu2005.lu/en/actualites/conseil/2005/06/ 17 conseur-decl/index.html. 
revoked and there is no reason to believe that it will not continue to produce the increasingly important effects it already has had on political and judicial practice at national and EU levels, but also beyond as exemplified in the European Court of Human Rights' (ECtHR) recent case law. ${ }^{7}$ Finally, now that the principle that the EU should seek accession to the European Convention on Human Rights (ECHR $)^{8}$ has finally been materially accepted by the Member States through Article I-9, TCE after 25 years of discussion, ${ }^{9}$ it is difficult to see how such a politically important decision could simply not be acted upon in the near future.

It should come as no surprise therefore that, in response to the question von Bogdandy provocatively raised five years ago as to whether the EU was or could be what he referred to as a 'human rights organisation, ${ }^{10}$ arguments in favour of the EU developing into a global or post-national ${ }^{11}$ human rights organisation, regime or framework now abound. ${ }^{12}$ If this may be an object of concern for those who regret the ad nauseam analysis of the human rights issue in the $\mathrm{EU}^{13}$ or to those who regard the whole debate as closed by the constitutionalisation of the Charter, others argue, on the contrary, that 'the best is yet to come' in terms of human rights protection in the EU. ${ }^{14}$ What most of these arguments leave open, however, is what it is precisely that we should understand by a global 'human rights organisation', 'framework' or 'regime' and how these terms differ from one another. Without a clear idea of what should constitute post-national human rights protection and

7 See, for example, Eeckhout, 'The EU Charter of Fundamental Rights and the Federal Question', (2002) 39 Common Market Law Review 945; Jacobs, 'Human Rights in the EU: The Role of the Court of Justice', (2001) 26 European Law Review 331. See, for example, C-112/00, Schmidberger Internationale Transporte and Planzüge $v$ Austria [2003] ECR I-5659; and Application Nos 52562/99 and 52620/99, Soerensen and Rasmussen v Denmark Decision of the European Court of Human Rights of 11 January 2006.

8 ETS No. 5

9 See Dutheil de la Rochère, supra n. 4 at 352-3; and Lawson, 'Human Rights: The Best is Yet to Come', (2005) 1 European Constitutional Law Review 27 at 31-3.

10 von Bogdandy, supra n. 2.

11 In this article, I am using the term 'post-national' as a generic term to mean strictly 'non-national'. It should not be taken to mean that post-national law supplants and replaces national law, as 'supranational' law would; it can, and should, coexist with national law. Moreover, 'post-national' law is broader than 'international' law as it does not have the specific meaning of 'between States' and captures any laws amongst States, individuals and/or other kinds of entities such as international organisations and NGOs.

12 See, for example, Alston and Weiler, "An "Ever Closer Union" in Need of a Human Rights Policy: The European Union and Human Rights', in Alston et al. (eds), The EU and Human Rights (Oxford: Oxford University Press, 1999) 3; Eeckhout, supra n. 7; Williams, 'The (Im)possibility of the European Union as a Global Human Rights Regime', in Brownsword (ed.), Global Governance and the Quest for Justice, Volume IV: Human Rights (Oxford: Hart Publishing, 2004) 69, who speaks interchangeably of a human rights 'regime', 'organisation', 'framework' or 'policy'.

13 See Weiler, 'European Citizenship and Human Rights', in Winter et al. (eds), Reforming the Treaty of the European Union (The Hague: Kluwer International Law, 1996) 57 at 77. Lawson, supra n. 9 at 27. 
an account of what we should expect from an institution ${ }^{15}$ of human rights protection, it is difficult to assess the EU in this light. This article will suggest a way in which institutional design and responsibilities can be conceptualised in the post-national context of human rights protection. Another difficulty with current accounts of human rights protection in the EU is that they mostly restrict themselves to a descriptive account of new developments in the field of EU human rights protection and omit a normative argument as to why these developments are desirable in the first place in the current global context. ${ }^{16}$ In the present article, therefore, I would like to argue that the EU not only has the capacity, but that it should in fact become a new kind of a post-national human rights institution lato sensu. This article is an extension of a first and general argument for a conception of the EU qua a post-national institution of global justice. ${ }^{17}$ It applies some of the normative considerations developed in that argument to the institutional responsibilities of the EU as a new form of post-national human rights institution. ${ }^{18}$ This article also draws on human rights theories to develop adequate criteria for the design of institutions of human rights protection, criteria which can then be applied to the EU to assess its transformations in the field of human rights protection and the scope for reform of its organs. Arguments go both ways, however, and if human rights theories apply to the EU and justify some institutional reforms, the EU also constitutes an interesting paradigm of a global multi-level human rights

15 In the present article, I am using the term 'institution' in a generic political sense to encompass all legally organised entities, such as organisations, etc., as well as their inner 'organs', such as parliamentary assemblies, committees of ministers, etc., and inner 'bodies' such as consultative agencies or committees. As such, this use of the term should not be identified with the specific legal use of the term within EU law where the EU is an 'organisation' composed of organs which are referred to as 'institutions' (Article 7, ECT) as well as of various 'bodies' such as the Committee of Regions. A human rights 'institution' can then be said to dispose of a legally structured 'framework' in which a certain 'regime' of human rights can be enforced. I will come back to the exact definition of human rights institution below. von Bogdandy, supra n. 2 and Williams, supra n. 12 are exceptions.

17 Besson, 'The European Union Qua Global Justice Agent' [forthcoming]. In the present article, I am referring to the EU as a post-national institution and legal order; it is indeed neither a supranational European State and State-like legal order (among others it lacks a demos and coercive force), nor a mere international organisation and legal order (evidence for this may be found in the primacy and direct effect of EU law, majority voting, the ECJ's compulsory jurisdiction, etc.). Space precludes discussing these issues anew in this article, but see for a discussion of the post-national nature of the EU and its law, Weiler and Wind, 'Introduction: European Constitutionalism beyond the State', in Weiler and Wind (eds), European Constitutionalism Beyond the State (Cambridge: Cambridge University Press, 2003) 1; Walker, 'Post-National Constitutionalism and the Problem of Translation', in Weiler and Wind (eds), ibid., 27; and Shaw and Wiener, 'The Paradox of the 'European Polity', in Green Cowles and Smith (eds), The State of the European Union, Vol. 5 (Oxford: Oxford University Press, 2000) 64.

18 The present article refers to 'obligations', 'duties' and 'responsibilities' interchangeably in the context of global justice. See O’Neill, 'Global Justice: Whose Obligations?', in Chatterjee (ed.), The Ethics of Assistance: Morality and the Distant Needy (Cambridge: Cambridge University Press, 2004) 242 at 248. 
institution which could then be used as a source of inspiration for further global institutional developments.

The present article is structured so as to reflect the different layers in the argument. In Section 2, it is important to start by presenting a few methodological considerations underlying the article's approach, and in particular, the dialectical relationship between human rights practice and normative considerations. Section 3 discusses issues pertaining to the theory and reality of human rights, in order to dissociate the existence of human rights from their institutional effectivity and to unpack the relationship between the content of human rights and the design of those institutions which will be vested with their protection. In Section 4, I would like to discuss the institutional dimension of human rights protection, and in particular define some ideal characteristics of a global human rights institutional framework. Section 5 assesses the current situation in terms of human rights protection in the EU and evidence that the EU is developing a stronger human rights protection framework. Section 6 discusses arguments for the development of the EU qua a human rights institution, before considering ways in which that framework may be improved to match the characteristics of an ideal human rights institution and how one may hope to develop a new kind of human rights institution in the EU.

\section{Methodological Considerations}

The connection between human rights theories ${ }^{19}$ and observations pertaining to the global institutional responsibilities of the EU raises complex methodological issues. ${ }^{20}$ Most ideal normative questions 'lead to normative-pragmatic questions belonging to non-ideal theory, especially of how best to construct and establish global institutions securing global justice. ${ }^{21}$ True, one may argue

19 For reasons of clarity, and in order to comply with most authors' choice in the matter (see, for example, O'Neill, supra n. 18; and Pogge, World Poverty and Human Rights (New York: Polity Press, 2002)), I am not distinguishing between demands of justice and human rights in this article, although demands of justice have a broader scope and encompass demands that are not strictly rights-based. A reason for not distinguishing them too closely lies in the development of the theory of universal human rights and obligations, and hence of accounts of the institutional dimension of the fulfilment of those obligations. See Pogge, 'Human Rights and Human Responsibility', in de Greiff and Cronin (eds), Global Justice (Cambridge, MA/London: MIT Press, 2002) 151; Beitz, 'What Human Rights Mean', (2003) 132:1 Daedalus 36; and Beitz, 'Human Rights and the Law of Peoples', in Chatterjee (ed.), supra n. 18, 193. See, however, on the importance of the distinction, Griffin, 'Discrepancies Between the Best Philosophical Account of Human Rights and the International Law of Human Rights', (2001) 101 Proceedings of the Aristotelian Society 1; and Tasioulas, 'Human Rights, Universality and the Values of Personhood: Retracing Griffin's Steps', (2002) 10 European Journal of Philosophy 79.

20 This section is largely inspired by the methodological considerations in Besson, supra n. 17.

21 Gosepath, 'The Global Scope of Justice', in Pogge (ed.), Global Justice (Cambridge: Blackwell, 2001) 145. 
that these theories have different audiences and that generally political theory should be kept distinct from politics. However, the distance can become so great that it impairs the capacity of theory to provide a useful assessment of existing institutional arrangements and to have an impact on them. ${ }^{22}$

A dynamic and reflexive approach is clearly needed, therefore, in order to discuss the aspects of human rights protection which reflect both normative demands and the existing political structure in Europe. ${ }^{23}$ A combination between a 'top to bottom' and a 'bottom to top' approach is required that allows for a certain influence of the post-national political and legal reality on normative considerations, while also, in turn, constraining that institutional reality with those very normative considerations. ${ }^{24}$ The 'top to bottom' approach is of crucial importance for the definition of those appropriate normative goals which might then be realised by real institutional reforms. ${ }^{25}$ Drawing normative rules from an existing institutional reality would indeed fall prey to the naturalistic fallacy. The 'bottom to top' approach is, however, of equal pertinence. Normative theory can only reform what there is and hence needs to rely on accurate empirical data. ${ }^{26}$ Moreover, normative theory looks for certain recognisable phenomena, such as legitimating consensus, and the feasibility of these phenomena depends on an assessment of existing practical constraints. ${ }^{27}$

It is therefore very important to strike the right balance between 'top to bottom' and 'bottom to top' approaches to global justice and human rights, in order to avoid the Charybdis of empty ethical universalism, on the one hand, or the Scylla of insufficiently demanding particularism, on the other. ${ }^{28}$ As Beitz rightly argues,

[t]heory has to begin somewhere. We begin with the observation that there is an international practice of human rights, and we ask some distinctively theoretical questions. [...] Whereas present practice is the beginning, it need not be the end; in fact, it would be surprising if a Metaphilosophy 1.

23 See Rawls, A Theory of Justice (Cambridge, MA: The Belknap Press, 1971); and Follesdal, 'Legitimacy Theories of the European Union', ARENA Working Paper 04/15.

24 See Gosepath, supra n. 21; and Gosepath, 'Globale Gerechtigkeit und Subsidiarität. Zur internen Beschränkung einer subsidiären und föderalen Weltrepublik', in Gosepath and Merle (eds), Weltrepublik: Globalisierung und Demokratie (München: Verlag Beck, 2002) 74. See also in the European context, Nicolaïdis and Lacroix, 'Order and Justice Beyond the NationState: Europe's Competing Paradigms', in Foot, Gaddis and Hurrell (eds), Order and Justice in International Relations (Oxford: Oxford University Press, 2003) 125 at 128, whose alternative paradigms both reflect and constrain European reality. See Gosepath, 'Globale Gerechtigkeit', ibid. at 74.

26 See Gosepath, ibid. at 75; and Hurrell, 'Order and Justice in International Relations: What is at Stake?', in Foot, Gaddis and Hurrell (eds), Order and Justice in International Relations (Oxford: Oxford University Press, 2003) 24 at 34. 
critical theory of human rights did not argue for revisions in the practice-conceivably substantial ones. [...] To dismiss the practice because it doesn't conform to a received philosophical construction seems to me dogmatic in the most unconstructive way. ${ }^{29}$

The advantage of the proposed combined approach to institutions lies in its reflexivity. Institutions are not seen as static, self-interested and amoral entities within the transnational sphere, while moral principles do not appear as castles in the air without any connexion to real phenomena. In fact, institutions can actually reflect, as well as shape, perceptions of human rights, and their role is crucial with regard to human rights concerns beyond the State. ${ }^{30}$ In this context, the EU can be used as a pioneering example against which one should test institutional concerns in the human rights context, without, however, necessarily being taken as an absolute model and an optimal outcome, given the constant need for institutional reform. ${ }^{31}$

\section{The Theory and Reality of Human Rights}

Before turning to the institutional dimension of human rights protection, it is important to clarify the relationship between the existence of human rights and their institutional effectivity. To do so, I will start with a few considerations in human rights theory and will then turn to the difficult question of the reality of human rights. ${ }^{32}$

\section{A. The Theory of Human Rights}

A discussion of the institutional implications of human rights protection at a global level requires a precise account of human rights per se. Scope precludes providing an exhaustive account here, but a few remarks are in order. ${ }^{33}$

Although human rights constitute an uncontestable part of contemporary law and politics, their positive guarantees are largely general and vague and their exact nature and consequences remain, as a result,

29 Beitz, 'What Human Rights Mean', supra n. 19 at 46.

30 See Nicolaïdis and Lacroix, supra n. 24 at 153.

31 Ibid. at 137.

32 Of course, the distinction between the theory and the reality of human rights is slightly artificial, since their theoretical justifications affect their reality and their reality should feed their theoretical conceptualisations. See Nickel, Making Sense of Human Rights: Philosophical Reflections on the Universal Declaration of Human Rights (Berkeley, CA: University of California Press, 1987); and Griffin, 'First Steps in an Account of Human Rights', (2001) 9 European Journal of Philosophy 306.

33 See Besson, The Morality of Conflict. Reasonable Disagreement and the Law (Oxford: Hart Publishing, 2005) at Chapter 12 for a more extensive discussion of human rights theory. 
controversial in moral theory. ${ }^{34}$ In what follows, I understand human rights primarily as rights, albeit of a special kind and of a special intensity. ${ }^{35}$ In a nutshell, human rights are the rights human beings have simply by virtue of being human. ${ }^{36}$ As such, they are rights which protect fundamental universal and general interests. Human rights, like rights, can be understood as a normative relationship between an addressee and a beneficiary that has a certain object. ${ }^{37}$ Whereas beneficiaries are mostly individuals, addressees may be both individuals and institutional agents. ${ }^{38}$ Even when human rights' addressees are individuals, institutions are usually vested with parallel positive duties to prevent human rights violations among individuals. These imply setting up judicial remedies, but also taking legislative and executive measures. As such, the institutional dimension of human rights is always implied in the interactional account of human rights defended here. ${ }^{39}$

Producing an introductory account of the nature of human rights is made even more difficult as the relationship between moral and legal rights itself is unclear. Some theories of rights assume that everything that is said about rights applies equally to moral and legal rights, whereas other theories have concentrated on either moral rights ${ }^{40}$ or legal rights. ${ }^{41}$ In this article, I propose an explanation of human rights in general which can be applied to moral and legal rights equally, with the latter ensuring the legal recognition of some protected interests besides other institutional rights. ${ }^{42}$ In the following discussion, I will distinguish between fundamental moral rights and their recognition through legal rights.

See, for example, Nickel, supra n. 32; Nickel, 'Human Rights', in Zalta (ed.), Stanford Encyclopedia of Philosophy, available at: http://plato.stanford.edu; and Nickel, Making Sense of Human Rights, 2nd edn (Washington, DC: Georgetown University Press, 2004). Unless specified, references to 'rights' encompass 'human rights' in what follows.

36 Compare, however, Pogge, World Poverty and Human Rights, supra n. 19, who understands 'human rights' not as a special kind of rights, but as a new self-standing notion. See Besson, 'Human Rights, Institutional Duties and Cosmopolitan Responsibilities', (2003) 23 Oxford Journal of Legal Studies 507 for a critique.

See, for example, Alexy, 'Die Institutionalisierung der Menschenrechte im demokratischen Verfassungsstaat', in Gosepath and Lohmann (eds), Die Philosophie der Menschenrechte (Frankfurt: Suhrkamp, 1997) 244.

38 Compare, however, Pogge, World Poverty and Human Rights, supra n. 19, who refers to Rawls, The Law of Peoples (Cambridge, MA: Harvard University Press, 1999) and his institutional account of justice and human rights.

39 On the opposition between interactional and institutional accounts of human rights, see Pogge, 'On the Site of Distributive Justice: Reflections on Cohen and Murphy', (2000) 29 Philosophy and Public Affairs 137. Compare Cohen, 'Where the Action Is: On the Site of Distributive Justice', (1997) 26 Philosophy and Public Affairs 3; and Murphy, 'Institutions and the Demands of Justice', (1998) 27 Philosophy and Public Affairs 251.

40 See Tugendhat, 'Die Kontroverse um die Menschenrechte', in Gosepath and Lohmann (eds), supra n. 37,48 .

41 See Hart, 'Definition and Theory in Jurisprudence', (1954) 70 Law Quarterly Review 49; and Hohfeld, Fundamental Legal Conceptions as Applied in Judicial Reasoning (Westport: Greenwood, 1978). See Raz, 'On the Nature of Rights', (1984) 93 Mind 194. 


\section{(i) Fundamental moral rights}

In this section, I will first present a modified account of the interest theory of rights, before presenting in more detail how rights relate to interests and duties.

\section{The modified interest theory of rights}

Three main theories of the nature of rights have been defended with varying success. The will theory of rights singles out right-bearers by virtue of the power they have over the duty in question so that their choice is sufficient to discharge another of the duty requirement. ${ }^{43}$ There are many difficulties with this theory, including, most importantly, the fact that it does not allow discussion about rights in advance of determining who exactly is under the relevant duty. ${ }^{44}$ Besides, by allowing right-holders to set aside the duty-bearer's duties to respect their rights, the will theory of rights does not account for the existence of the rights we regard as inalienable and as linked to objective aspects of our well-being, such as human rights. ${ }^{45}$ In contrast, according to the interest theory of rights, a person has a right if an aspect of her well-being (her interest) is a sufficient reason for holding some other person(s) to be under a duty. ${ }^{46}$ It is the most influential theory of rights to date. ${ }^{47}$ The advantage of the interest theory of rights is, first, that it makes it possible to argue for the recognition of a right before specifying which duties correspond to it. ${ }^{48}$ Second, the interest theory does not preclude any of the means, and duties, that could help protect the right - thus identifying the right with a sufficient ground for holding other individuals under all the duties necessary, rather than in terms of the details of these duties. $^{49}$

Finally, according to the status theory of rights, rights express the recognition of a person's status as a being who has a high, even if not an absolute, level of inviolability. ${ }^{50}$ The status a right protects is not so much in a person's interests, as it is a status that makes her interests worth protecting. Such a right is based on a person's status and is not necessarily related to University Press, 1984) 77.

44 See Waldron, 'Introduction', in Waldron (ed.), ibid. 1 at 10. See Harel, 'Theories of Rights', in Golding and Edmundson (eds), The Blackwell Guide to the Philosophy of Law and Legal Theory (Oxford: Blackwell, 2004) 191 at 193-7 for a more elaborate discussion and critique of both models. See Waldron, ibid. at 9.

See Raz, supra n. 42 at 195. On the different versions of Raz's definition of rights, see Kamm, 'Rights', in Coleman and Shapiro (eds), The Oxford Handbook of Jurisprudence and Philosophy of Law (Oxford: Oxford University Press, 2002) 476 at 484 et seq. See MacCormick, 'Rights in Legislation', in Raz and Hacker (eds), Law, Morality and Society (Oxford: Clarendon, 1977) 189 at 192 et seq.

48 Ibid. at 201

49 See Waldron, supra n. 44 at 10-1.

50 See Kamm, 'Conflicts of Rights. Typology, Methodology and Nonconsequentialism', (2001) 7 Legal Theory 239 at 242-7; and Kamm, supra n. 46 at 492-3. 
any aspect of her well-being. ${ }^{51}$ An interpretation of the status theory (modified interest theory) allows us to keep an interest-based account of rights while attenuating some of its consequences. As Kamm rightly argues, applied strictly, the interest theory of rights is blind to the circumstances in which a right is infringed. ${ }^{52}$ A status-based filter on rights therefore permits the application of the interest theory to be refined to prevent cases of infringement of rights that would deny any status to the right-holder. ${ }^{53}$ According to the modified interest theory of rights, then, most rights are based on interests, but some are aimed at recognising a person's status and inviolability which lie at the foundations of her interests. This is clearly the case for most fundamental rights, whose special weight does not depend only on the importance of the protected interests, but also on the fundamental status they protect. ${ }^{54}$ The modified interest theory also captures the importance of the so-called fundamental core of human rights known to certain constitutional traditions in Europe. ${ }^{55}$

\section{From interests to duties}

In the modified interest theory of rights, human rights qua normative relationships are intermediaries between interests and duties. ${ }^{56}$

Rights are founded on interests. Only interests of ultimate value can found rights; ${ }^{57}$ they are interests which are regarded as fundamental for the wellbeing of a person. They include individual interests when these constitute a part of a person's well-being in an objective sense. They also extend to others' interests and even to the common good in some cases. ${ }^{58}$ The fundamental nature of the protected interests will have to be determined by reference to the context and time rather than established once and for all. ${ }^{59}$ For a right to be recognised, therefore, a sufficient interest must be established and weighed against other interests and considerations with which it might conflict in a particular social context. $^{60}$ This implies that a lot of

51 See Kamm, supra n. 46 at 485.

52 Ibid. at 506 et seq.

53 See Kamm, supra n. 50 at 244.

54 Such a reinterpretation is in line with Raz's contentions about the relationship between fundamental or constitutional rights and the common good and the fact that in some cases the stringency of rights seems greater than the weight of the individual interests they protect. See Raz, 'Rights and Individual Well-Being', (1992) 5 Ratio Juris 127 at 135; and Raz, 'Rights in Politics', in Tasioulas (ed.), Law, Values and Social Practices (Aldershot, Dartmouth, 1997) 75 at 83. See also Harel, supra n. 44 at 202.

See Besson, supra n. 33.

See Raz, supra n. 42 at 208.

On the entities which can have such ultimate-valued interests and the nature of these interests, see Harel, supra n. 44 at $193-7$.

See Raz, 'Rights and Individual Well-Being', supra n. 54; and Raz, 'Rights in Politics', supra n. 54 at 83.

Compare Griffin, supra n. 32.

See Raz, Value, Respect and Attachment (Cambridge: Cambridge University Press, 2001) at 202 on the importance of social practices when defining the scope and content of rights. 
weighing and balancing ${ }^{61}$ will have to be done before a right is identified, in order to establish exactly where the special importance of the right lies. ${ }^{62}$

Rights ground duties. Rights are reasons for holding others in duty. Many have deduced from this that rights and duties are correlatives. However, the correlativity between them is not immediate. ${ }^{63}$ As rights come logically into existence prior to the specification of the duties they then justify, it is possible to have rights without duties. ${ }^{64}$ Of course, once a specific duty is grounded, ${ }^{65}$ it will be correlative to the specific right which flows from the general right and which grounds the duty. ${ }^{66}$ The relationship between rights and duties is therefore normative or justificatory, rather than symmetrical. ${ }^{67}$ It follows that a right might provide for the imposition of many duties and not only one. Besides, rights have a dynamic nature and, as such, successive specific duties can be grounded on a right depending on the circumstances. ${ }^{68}$ One right may therefore be correlative to many different duties across time. ${ }^{69}$ This is particularly important in the case of human rights which are necessarily general and usually entrenched in long-lasting legal instruments, and can therefore be specified anew in each concrete case.

In these circumstances, one may wonder why there is a need for rights at

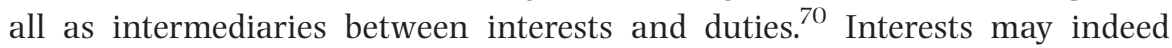
change, thus changing the recognised rights. Rights themselves may change, thus questioning what had been guaranteed. Finally, duties themselves arise and change in relation to the need of protection of the recognised interests. In fact, it is this very dimension of change and conflict which justifies the recognition of rights. Not only do rights provide a way to save time and energy in terms of allowing us to rely on the superiority of some interests over others, but also, and more importantly, they provide us with an intermediary level interest it protects. Talk of the 'weight' and 'balancing' of rights and interests is metaphorical, of course.

62 See Waldron, supra n. 44 at 14. See also Raz, supra n. 42 at 200 and 209; and Marmor, 'On the Limits of Rights', (1997) 16 Law and Philosophy 1 at 10.

63 One may argue that this does not question the Hohfeldian conception of correlativity as the latter is meant as a stipulation, rather than as an empirical claim. See Raz, 'Disagreement in Politics', (1998) 43 American Journal of Jurisprudence 25.

64 It is also possible to have duties without rights. See Raz, Ethics in the Public Domain (Oxford: Oxford University, 1995); and Feinberg, 'In Defense of Moral Rights', in Feinberg (ed.), Problems at the Roots of Law: Essays in Legal and Political Theory (Oxford: Oxford University Press, 2003) 37. See MacCormick, supra n. 47 at 199-202; Raz, supra n. 42 at 196-200; and Kamm, supra n. 46 at 480 .

66 See Raz, supra n. 63 at 42.

67 See Marmor, supra n. 62 at 3.

68 See Raz, supra n. 42 at 197-9.

69 See Waldron, Liberal Rights: Collected Papers, 1981-1991 (Cambridge: Cambridge University Press, 1993) at 212 et seq. See Raz, supra n. 42 at 208-9. 
of agreement. ${ }^{71}$ Even if this agreement is not meant to last, it is a base we need to agree on in order to disagree further, about duties for instance. One may even say it is a way to make sure we disagree further about rights. ${ }^{72}$ This is particularly true of fundamental rights, as they recognise and individuate interests over which we are bound to disagree later and over which we should, in fact, keep disagreeing.

\section{(ii) Fundamental legal rights}

According to Raz, if rights are protected interests in that a person has a right if and only if an interest of his is a sufficient ground for holding another to be subject to a duty then legal rights are legally protected interests. ${ }^{73}$ According to this definition, a legal right comes into existence in two steps. ${ }^{74}$ First of all, an individual has a right if an interest of hers is sufficient to hold another to be subject of a duty. Second, her right is a legal right if her interest is recognised by law, that is, if the law holds her interest to be a sufficient ground to hold another to be subject to a duty. ${ }^{75}$ This explains how, in some cases, a legal rule may seem to be conferring a right in protecting someone's interest without necessarily conferring such a right in practice, because there is no such interest to protect, or at least not in that way. In this case, the valid legal rule has the legal form of a legal right, but not its content. ${ }^{76}$

It follows that legal rights may be regarded as moral rights. Of course, not all moral rights are or should be legally recognised, on the one hand. There can be moral rights which do not give rise to legal rights. Rights should not, therefore, necessarily be understood as 'moral rights to have legal rights' along Feinberg's argument. $^{77}$ Law need not always be a better protection of rights-protected interests than other means. ${ }^{78}$ Nor, on the other hand, does this mean that legal rights necessarily always pre-exist as independent moral rights. Some do and are legally recognised moral rights, but others are legally created moral rights. ${ }^{79}$ In some cases, the law may change a person's interests, thus in a sense creating the interest which is the foundation of the right. As Raz puts it,

See Marmor, supra n. 62 at 15-6.

See Besson, supra n. 33.

Raz, 'Legal Rights', (1984) 4 Oxford Journal of Legal Studies 1 at 12.

Ibid. at 14.

Ibid.

See Raz, 'Reasoning with Rules', (2001) 54 Current Legal Problems 1 at 6, on the normative gap that is intrinsic to reasoning with legal rules.

See, for example, Feinberg, supra n. 64. See, in the case of human rights, Alexy, supra n. 37; and Habermas, Die postnationale Konstellation (Frankfurt: Suhrkamp, 1998).

See for example, Tasioulas, 'The Moral Reality of Human Rights', in Pogge (ed.), Freedom from Poverty as a Human Right; Who Owes What to the Very Poor? (Oxford: Oxford University Press, 2006) forthcoming; Waldron, Law and Disagreement (Oxford: Oxford University Press, 1999); and Pogge, 'Human Rights and Human Responsibility', supra n. 19.

See Raz, supra n. 73 at 16-7. 
'legal obligations are real (moral) duties arising out of the law'. ${ }^{80}$ The general account of moral rights defended in the prior section applies therefore to legal rights whether or not a legal right corresponds to a pre-existing moral right.

So far I have been addressing the issue of legal rights in general. The legal rights we concern ourselves with in this article are fundamental rights. Fundamental rights are regarded as more fundamental than other legal rights because they often protect common goods apart from individual interests. Besides, even when they protect fundamental interests, they do so in a way that pays more attention to an individual's fundamental status and inviolability than ordinary legal rights. ${ }^{81}$ They are therefore usually entrenched and protected from ordinary legislative revisions, either through constitutional protection at the national level or through human rights treaties and conventions at the international level. Thus, they differ both formally and substantively from ordinary legal rights.

\section{B. The Reality of Human Rights}

Besides numerous controversies about the exact nature of human rights and their relationship to interests and duties, it is their relationship to institutional reality which has recently become the centre of interest. The question that is commonly raised can be phrased: is the effectivity of human rights a condition of their existence or rather a consequence? ${ }^{82}$ We know that human rights have to be institutionally enforced in practice; it is in fact the whole point of rights to give rise to obligations to enforce them. We also know, however, that rights are rarely fully enforced and hence entirely effective in practice. Hence, the concern about their effectivity and how to connect it back to their very existence.

The question of human rights' effectivity is particularly relevant for the institutional design of global human rights protection frameworks such as that in the EU. The institutional protection of human rights is indeed a central element of their effectivity. Moreover, in the absence of a global State, institutional enforcement of human rights at the global level is necessarily less exhaustive than national mechanisms of enforcement. This gives rise to different conclusions: either the existing institutional framework at the post-national

80 Ibid. at $16-7$.

81 See Raz, 'Rights and Individual Well-Being', supra n. 54 at 135 et seq.; and Raz, 'Rights in Politics', supra n. 54 at 83.

82 This question applies to both moral and legal human rights, but mostly to the latter given the heightened concern for the effectivity of the latter. In fact, the legal translation of human rights may even be regarded as the first step towards their enforcement. As I explained before, however, and contrary to authors like Habermas or Alexy, I do not regard the legal translation of a moral right as an automatic right to legalisation flowing from the existence of a moral right (i.e. a moral right to $\mathrm{X}$ amounts to a moral right to a legal right to $\mathrm{X}$ ). In what follows, therefore, I will regard the legalisation of human rights as an important part of their institutional enforcement and discuss it as a particular instance of the latter. 
level conditions the existence of the human rights we can have or, conversely, the latter's existence and content influence the post-national institutions we set up to protect them. The gist of this article's argument will obviously depend on the answer to this question. It is only if human rights can influence the kind of post-national protection institutions we set up that the whole question of the ideal institutional design and assessment of the transformation of the EU human rights protection framework can be raised.

According to some authors, the moral reality of human rights, and hence their recognition depend on their effectivity in practice. Rights, which are neither claimable nor executable, are regarded as mere rhetorical or 'manifesto' rights. A manifesto right ${ }^{83}$ is a right which cannot generally be respected at the time of utterance, whose addressee cannot yet be determined in a secure manner, and, when she is specified, cannot ensure the respect of the right in a general fashion. Authors can be split into two groups depending on the degree of enforceability that they require for rights to exist. According to Feinberg and O'Neill, ${ }^{84}$ human rights should be claimable in the sense that there should be means to claim that they should be respected, whether or not they can then be respected. However, according to Geuss and James, ${ }^{85}$ the moral reality of human rights requires more than mere claimability; it also implies executability. Of course, this does not imply that human rights need to be executed to exist, but that this execution should at least be possible. There should be mechanisms to enforce them effectively and, in particular, institutions, enforcement agents and the ability for the beneficiaries to require their enforcement.

However, this approach to human rights is too restrictive. True, rights should be feasible along the lines of the 'ought implies can' adage, but feasibility need not yet mean claimability or effectivity. Effectivity does matter, but it is a requirement and hence a consequence of human rights, rather than a condition. Of course, rights call for respect and hence effectivity, but this is a consequence of their existence in the first place. ${ }^{86}$ Confirmation may be found, for instance, in a reading of Article 28 of the Universal Declaration on Human Rights 1948 (UDHR). ${ }^{87}$ This can be explained, first of all, by reference to the relationship between human rights and duties, which are not absolutely correlative, but stand in a justificatory relationship. The interest theory of rights implies the dynamic nature of human rights which pre-exist the specification of the duties to which they give rise in each case. This excludes, as a consequence,

See Feinberg, supra n. 64.

See Feinberg, ibid.; O'Neill, Bounds of Justice (Cambridge: Cambridge University Press, 2000); and O'Neill, supra n. 18.

See Geuss, 'Outside Ethics', (2003) 11 European Journal of Philosophy 29; and James, 'Rights as Enforceable Claims', [2003] Proceedings of the Aristotelian Society 133.

See Nickel, supra n. 32 at 35: 'Legal enforcement is often important to making rights effective, but such enforcement is not essential to the existence of rights'.

GA Res. 217 A (III), 10 December 1948, A/810 at 7. 
the logical dependence of the existence of rights on the enforcement of the duties they give rise to. It is important to distinguish a human right from the reasons it creates. $^{88}$ Moreover, not all rights are claim-rights; liberties and immunities, for instance, cannot be claimed at all. Finally, there are many ways of claiming rights and many need not be institutionalised at all. ${ }^{89}$ Thus, we may have human rights no one can as yet fulfil entirely and which may later impose duties on institutions which cannot yet comply with those duties, provided all available and capable institutions can be asked to do their best to respect them. It is important, therefore, not to confuse the existence of a human right with the enforcement of that right. Human rights' institutional reality stems from their moral reality, but is not one of its conditions.

\section{Human Rights and Post-National Institutions}

Although neither executability nor claimability are conditions of the recognition of human rights, they constitute its primary normative consequence. Human rights give rise to duties of enforcement, which should be optimised in each case. And this is precisely why the institutional design and allocation of responsibilities among potential agents is crucial to the realisation of those duties. As such, it is essential to establish criteria of institutional design which can then be used to assess the quality of human rights' institutional enforcement in practice. ${ }^{90}$ In this section, I will address the question of the design of postnational human rights institutions in a general fashion. ${ }^{91}$ To do so, the section starts by discussing the different institutional agents of protection of human rights and the scope and allocation of their responsibilities, before addressing the issue of institutional design stricto sensu.

\section{A. Human Rights and Institutional Agency}

Among the different types of post-national human rights institutions, one should distinguish between primary and secondary agents. According to O'Neill, primary agents are those who have the capacity to determine how human rights are to be institutionalised within a certain domain. In contrast, secondary agents are those agents constructed by primary agents to meet the demands of justice set by them, most evidently by conforming to any legal

See Tasioulas, supra n. 78; Pogge, 'Human Rights and Human Responsibility', supra n. 19; and Griffin, supra n. 32 .

See Nickel, supra n. 32.

In contrast, for those authors who link the existence of rights to their institutional effectivity, rights cannot influence normatively the institutions we have, since they would not exist without effective institutions. See, for example, O'Neill, supra n. 18.

This section, with the exception of C, is largely inspired by Besson, supra n. 17 . 
requirements they establish. ${ }^{92}$ Typically, primary agents have means of coercion by which they control the action of secondary agents.

Curiously, most cosmopolitan theories of human rights assume that global duties stop at State boundaries, or at least that, when they extend to post-national institutions, these are, at most, regarded as secondary agents of justice with secondary obligations. ${ }^{93}$ The UDHR, for instance, refers mostly to States as addressees of their corresponding obligations. ${ }^{94}$ True, practice shows that States remain central agents of justice despite intensive global changes. Globalisation is, however, currently reconfiguring power. ${ }^{95}$ Transnational $^{2}$ harm is no longer the only global harm one may be concerned about. ${ }^{96}$ Moreover, States can be weak and incapable of action. Even when such States are strong enough, they can no longer guarantee the protection of their citizens' and others' human rights on their own under circumstances of intensive globalisation. ${ }^{97}$ States can therefore no longer be deemed the sole and primary agents of human rights protection and redress in operation regarding transnational or other harms. ${ }^{98}$ Many non-State agents like NGOs, but also transnational, international and post-national institutions, whose contribution to justice is not regulated, defined and allocated by States only, and which can therefore function as primary agents of justice, can now contribute to the protection of human rights.

For obvious reasons, post-national institutional agency in the human rights context cannot be understood along the same lines as national agency. It is important, therefore, to delineate its contours in more detail. These are bound to be controversial, however. A working definition one may suggest is: any collective institutional structure that purports to intervene in human rights matters regardless of jurisdiction and which, itself, regards human rights as its key principle of governance. ${ }^{99}$ These post-national institutional actors include non-governmental transnational agencies, such as NGOs, as well as governmental transnational, international or supranational organisations. These potentially encompass the United Nations, the Council of Europe and other regional entities active in the human rights context. The question I will address later in this article is whether the EU can be deemed as one of them.

See O’Neill, 'Agents of Justice', in Pogge (ed.), supra n. 21, 188 at 189. See O'Neill, supra n. 18 at 242-4 and 249.

Ibid. at 243.

Ibid. at 256.

See Foot, 'Introduction', in Foot, Gaddis and Hurrell (eds), Order and Justice in International Relations (Oxford: Oxford University Press, 2003) 1 at 4-5.

See O'Neill, supra n. 18 at 246-7.

See Foot, supra n. 96; and Hurrell, supra n. 26.

See Williams, supra n. 12 at 70 who restricts, however, his definition to 'State agreed' structures. This restriction does not fit the post-national approach chosen in the present article. 


\section{B. Human Rights and Institutional Responsibility}

There is nothing unusual about ascribing obligations to institutions or groups of individuals. Like individuals, institutional and collective agents bring cognitive and decision-making capacities to bear on choices that initiate action and affect what happens. ${ }^{100}$ In this sense, non-State institutions do not differ from States.

If non-State institutional and collective agents can bear obligations of justice, it is important to distinguish the identification and scope of institutional obligations from the allocation of those obligations among institutions, although most of the time both issues will be interrelated in practice. ${ }^{101}$ The answer to the question of which obligations should be borne by which agent in a concrete case will depend on the relationship between the propositional content of human rights and the actual capacities of the putative agent. ${ }^{102}$ According to the interest-based theory of rights propounded here, ${ }^{103}$ specific obligations to respect the same general rights and underlying obligations need not always be the same, depending both on the circumstances and the specific agents targeted. Accordingly, the agents who ought to carry out specific obligations are those which, beside other conditions, ${ }^{104}$ can do so, and this specification of duties will depend on the circumstances in each case. ${ }^{105}$

The allocation of duties mirrors the relationship between obligations and capacities. It is not enough simply to assume that there will always be an effective and decent State to assign obligations of justice to other institutions. Any adequate assignment of obligations must allocate specific obligations to those with the necessary powers and skills to fulfil them. ${ }^{106}$ The reverse is also true: weak States cannot coherently be required to carry out tasks for which they are not competent. It is crucial, in view of these new circumstances, to accommodate new institutional agents in cosmopolitan theories of justice and to account for a plurality of agents of human rights protection that can fulfil their duties at the different levels at which they can be fulfilled most efficiently. ${ }^{107}$ This idea of a network of human rights protection institutions is exemplified, as we will see, in the EU, which combines post-national, transnational and national institutional layers. ${ }^{108}$

100 See O'Neill, supra n. 18 at 249.

$101 \quad$ Ibid. at 248.

102 Ibid. at 245 .

103 See, for example, Raz, supra n. 42; and Tasioulas, supra n. 78.

104 These conditions include among others the existence of an objective interest fundamental enough to hold someone else in duty: see, for example, Raz, supra n. 42.

105 See Besson, supra n. 33 at Chapter 12.

106 See O’Neill, supra n. 18 at 250-1. See also Gosepath, supra n. 21 at 163.

107 O'Neill, supra n. 18 at 250 and 258.

108 See, on the idea of a network of global institutions, Dryzek, 'Deliberative Democracy in Divided Societies. Alternatives to Agonism and Analgesia', (2005) 33 Political Theory 218; and Archibugi, 'Cosmopolitan Democracy and Its Critics: A Review', (2004) 10 European Journal of International Relations 437. 


\section{Human Rights and Institutional Design}

As I have explained before, the existence of human rights qua protected interests does not depend on their institutional effectivity, but does give rise to duties of institutional enforcement. As we have just seen, the scope and allocation of these duties depend, on the one hand, on the interests protected by the human rights in each case and, on the other, on the capacities of the putative responsible agents. Adequate institutional design and the identification and enhancement of the capacities of the putative responsible agents to abide by their duties are crucial to an optimised realisation of those duties. After a short discussion of the idea of institutional design itself, I will define different criteria which might be used to assess an ideal institutional framework of human rights protection.

\section{(i) Institutional design in general}

Institutional design is best understood as a reflexive and dialectical exercise. It anticipates, first of all, what protected interests might generally require in order to increase the capacities of institutions to protect those interests and try to comply in advance with what might be demanded of these institutions. In a second stage, it looks back to the enforcement of the duties generated in concrete circumstances, to improve future designs. It amounts, in other words, to a 'back and forth' exercise between institutional practice and normative theory; the former influences the latter, but the latter should also condition the former.

While this dialectical approach to institutional design is clearly at work at the national level, where years of institutional experience have helped refine institutional frameworks, things are slightly more complex at the post-national level, where the process of mutual adjustment has only just started. Based on the proposed interest-based account of human rights and institutional responsibility, the institutional needs raised by existing human rights can easily be anticipated. It is clear, for instance, that the predominantly liberal rights one finds in current human rights protection instruments have had an influence on post-national institutional design which is almost purely judiciary-based. In fact, the wedge drives both ways. One may, for instance, revise existing human rights instruments to generate more proactive institutional frameworks. Thus, the emergence of new human rights, such as social rights, has already given rise to new agencies in human rights protection, and in particular to the development of NGOs, which are more able to enforce those rights than other existing post-national institutions. In this respect, it is interesting to assess the types of human rights the EU might be able to protect and how its institutions could be reformed to do this best. 
Following a constructivist approach, it can be said that institutions to be set up in the future can be "catalysts for change and agents of change, rather than unitary entities with fixed preferences that are difficult to change. ${ }^{109}$ Some authors like Kostakopoulou actually emphasise that agents

have the capacity to capitalise on the normative surplus of meaning and the progressive possibilities already present in accepted logics and existing conceptual resources nested within institution in order to develop new conceptions. [...] [Institutional change] is [...] more fluid, contingent, unpredictable and [...] transformative. ${ }^{110}$

This fluidity of institutional change reflects the dynamic nature of human rights and the many ways in which they can be protected. ${ }^{111}$

\section{(ii) Institutional criteria in the human rights context}

Different criteria for institutional design in the human rights context may be suggested. Specific constitutive elements of a post-national human rights institution should be defined if one is to assess existing institutions and propose new reforms to fit this ideal. As discussed before, a working definition of a human rights institution might be any collective institutional structure that purports to intervene in human rights matters regardless of jurisdiction and which itself regards human rights as its key principle of governance. ${ }^{112}$ Accordingly, we may define at least five general criteria which are constitutive of a good post-national human rights institution. Further criteria may be delineated in each case by reference to the specifically protected interests and the duties they give rise to in given circumstances.

\section{Institutional structure}

This first criterion is relatively straightforward. I have already discussed the external scope of institutional agency and the difference between primary and secondary institutional agents and will not come back to these issues here. What needs to be addressed, however, is the internal organisation of postnational human rights institutions. It may mirror a State with a combination

109 Kostakopoulou, 'Ideas, Norms and European Citizenship: Explaining Institutional Change', (2005) 68 Modern Law Review 233 at 236. Kostakopoulou argues against Checkel, 'The Constructivist Turn in International Relations', (1998) 50 World Politics 324, that institutional (as opposed to social) constructivism does not lack a theory of agency at all. See also Haas and Haas, 'Pragmatic Constructivism and the Study of International Institutions', (2002) 31 Millennium 573.

110 Kostakopoulou, ibid. at 236-7.

111 See Gosepath, 'Zur Begründungen sozialer Menschenrechte', in Gosepath and Lohmann (eds), Die Philosophie der Menschenrechte, supra n. 37 at 146; and Tasioulas, supra n. 78.

112 See Williams, supra n. 12 at 70. 
of legislative, executive and judicial powers. ${ }^{113}$ In most cases, however, post-national human rights institutions are only one-dimensional and very often merely judicial, as in the case of the ECtHR. This is a consequence of the material scope of application of these instruments that is limited to the activity of national institutions. As a result, one may feel the influence of the national conception of human rights protection on the internal organisation of human rights institutions. This is exemplified, for instance, by von Bogdandy's contention that the vision of reconstructing broad policy fields from the perspective of human rights might in the long run even corrupt the concept of a right as such, because the very essence of a right is that it is accorded immediate protection by the courts. ${ }^{114}$

\section{Human rights competence}

The second criterion for human rights institutional design is obviously a core competence in human rights protection. Only an institution which can place human rights at the core of its internal and external governance can be deemed a human rights institution. This may in turn give rise to different measures, whether human rights policy measures or more classical human rights enforcement measures.

\section{Global know-how}

If a human rights institution that is organised as such is to be deemed a post-national human rights institution, a third criterion needs to be added that makes its post-national dimension specific. Post-national human rights institutions can indeed play a role in human rights protection that is different from that of national human rights frameworks and is complementary to them. As such, their global know-how should be a crucial element of their design. What is meant by global know-how is a constellation of instruments of transnational and post-national trendsetting.

\section{Publicity and transparency}

A fourth criterion in the design of post-national human rights institutions is their publicity and transparency. These imply good information and, in principle, trigger deliberation, which is a crucial element of political legitimacy, in conditions of reasonable pluralism and disagreement. Human rights are very contestable objects and legitimacy of institutional decisions in this context is therefore essential.

113 See, for example, Alexy, supra n. 37 on the complex institutional structure required by fundamental rights protection at the State level.

114 von Bogdandy, supra n. 2 at 1316. 


\section{Democracy}

A final criterion that is related to the previous one is democracy. Not only should human rights institutions' decisions be transparent and public, but they should also be democratic and include all those affected by these decisions in the decision-making process. This inclusive nature is crucial to the legitimacy of their decisions and democratic deficit is still one of the major difficulties human rights institutions have to face. It would be a paradox indeed if those institutions whose primary function is to protect fundamental rights did not respect the 'right of rights', that of equal participation of all those affected in the elaboration of their other rights. ${ }^{115}$

\section{European Integration and Human Rights Protection}

In this section, I would like to present evidence that the EU has the capacity to become the first of a new kind of global human rights institution. Given the copious evidence to the contrary and the many critiques of the EU's hypocritical, defensive and negative approach to human rights, this statement obviously calls for a global account of human rights protection in the EU and it will be the purpose of this section to provide this, albeit in very general terms. ${ }^{116}$ I will start by presenting recent breakthroughs in European human rights practice, the objections it left unmet and the most recent evidence of transformation in the area.

\section{A. From Economic Integration to Human Rights Protection}

The founding European Community (EC) Treaties did not refer to the protection of fundamental rights and their first mentions in EC law pertained to economic comparative advantages as in the case of equality between men and women and anti-discrimination rights. Things started to change in the late 1960s when the European Court of Justice (ECJ) began to rule that respect for such rights was part of the legal heritage of the Community. ${ }^{117}$ This occurred in reaction to national constitutional courts' questioning of the primacy of European law and their threats not to apply it as long as it did not provide sufficient protection of fundamental rights at least equal to that provided by national constitutions

115 See Waldron, supra n. 78 at Chapter 11.

116 This section is largely inspired by Besson, supra n. 17.

117 See, for example, C-2/69, Stauder v City of Ulm [1969] ECR 419; C-11/70, Internationale Handelsgesellschaft v Einfuhr- und Vorratsstelle für Getreide und Futtermittel [1970] ECR 1125; C-4/73, Nold v Commission [1974] ECR, 491; C-5/88, Wachauf v Federal Republic of Germany [1989] ECR 2609; and C-260/89, ERT v DEP [1991] ECR I-2925. 
and international agreements. ${ }^{118}$ From then on, and this occurred gradually, EU institutions and Member States violating human rights in application or in derogation of an EU competence were deemed as violating the Community legal order; the latter was said to contain non-written general principles which entailed fundamental rights equivalent to, and inspired by, those in the ECHR and Member States' constitutional traditions.

The belated and defensive nature of EU fundamental rights protection has attracted numerous critiques and nourished deep scepticism about whether the EU's project of economic ordo-liberalism bears any relation to the project of a human rights organisation. ${ }^{119}$ Human rights were indeed originally brought in primarily to bind the EU and to protect national prerogatives in the area, and not to extend EU competences in any way or to constrain Member States any further. ${ }^{120}$ If Member States were bound by EU fundamental rights, it was not in their own fields of competence and the EU had no business telling them how best to protect human rights in their national sphere of competence. In fact, due to the Member States' resistance, there was, for a long time, no real proactive human rights policy in the EU. It is only from the early 1990s that a progressive consolidation of human rights protection started taking place both internally and externally.

This occurred, internally, through the different layers of treaty revisions in the Union starting with the first mention of human rights in the Preamble of the Single European Act in 1986. ${ }^{121}$ It continued with the adoption of Article 6 of the Maastricht Treaty, ${ }^{122}$ which was later amended and made justiciable in Amsterdam. According to this Article, human rights are protected by the EU. The Treaty of Amsterdam ${ }^{123}$ also introduced, in Article 7, the possibility to deprive a Member State violating human rights of some of its rights under the Treaty. Article 13 of the Consolidated Version of the Treaty establishing the European Community (ECT) ${ }^{124}$ gives the EC a legislating competence in the field of anti-discrimination law and has provided the legal basis for the 2000 anti-discrimination directives. In parallel to developments in primary law, European institutions have gradually taken practical initiatives in different areas of human rights protection since the early 1990s, in particular providing measures against xenophobia or gender discrimination. In 2000, the EU

118 See, for example, the German Federal Constitutional Court's decisions: Solange I BVerfGE 37, 271 (1974); Solange II BVerfGE 73, 339 (1986); and Brunner BVerfGE 89, 155 (1993).

119 See Coppel and O’Neill, ‘The European Court of Justice: Taking Rights Seriously', (1992) 29 Common Market Law Review 669.

120 See von Bogdandy, supra n. 2 at 1308: 'If these endeavours succeed, human rights would determine rather than simply limit the European legal system and would move to the forefront of its institutions' activity.'

121 [1986] OJ L 169/1.

122 [1992] OJ C 191/1.

123 [1997] OJ C 340/1.

124 [2002] OJ C 325/33. 
adopted a non-binding Charter of Fundamental Rights, which expressly, albeit non-exhaustively, guarantees rights inspired by the ECHR, Member States' constitutional traditions and general principles of EC law. The Charter may become binding as Part II of the TCE if it is ratified. ${ }^{125}$ The new Constitution actually expressly places human rights at the core of the Union's values and objectives (Articles 2 and 3 of the TCE). Last but not the least, it authorises the full accession of the EU to the ECHR in Article I-9 of the TCE; in so doing, it clarifies the EU's competence to accede which had previously been denied on the basis of the EC Treaty by the ECJ's 2/94 Opinion. ${ }^{126}$ In short, the constitutionalisation process places human rights at the heart of European integration. ${ }^{127}$ True, this process seems to have come to a halt, but besides the latter being foreseeably purely provisional and furthermore not being related to the constitutionalisation of the Charter itself, there is growing evidence that human rights now hold a central position in European case law and politics.

Externally, too, the EU has considerably increased its role in global human rights protection since the early 1990s. This has been the case in the context of economic agreements with developing countries, such as the 2000 Cotonou Convention, ${ }^{128}$ which have inserted the encouragement and mainstreaming of human rights considerations into development projects supported by the EU. This increase in external human rights presence may also be illustrated in the enlargement context and in particular by the European Initiative and Programme in Democracy and Human Rights and by the Copenhagen criteria for accession. More strikingly, the 2003 Athens Declaration reaffirmed the need to commit the Union 'to furthering respect for human dignity, liberty and human rights' and maintained that 'we will continue to uphold and defend fundamental rights, both inside and outside the European Union. ${ }^{129}$ Finally, Article III-193(1) of the TCE confirms that the Union's action on the international scene shall be guided by, and designed to advance in the wider world, the principles which have inspired its own creation, development and enlargement: democracy, the rule of law, the universality and indivisibility of human rights and fundamental freedoms.... Even though many of these external developments in the EU's role in human rights protection can be traced back to an economic rationale, the outcome is clearly positive and signals the EU's human rights awareness to the world.

125 For a detailed analysis of the implications of the constitutionalisation of the Charter for fundamental rights protection in the EU, see Lawson, supra n. 9.

126 Opinion 2/94, Accession by the Community to the European Convention for the Protection of Human Rights and Fundamental Freedoms [1996] ECR I-1759.

127 See the Preamble of the Charter of Fundamental Rights in Part II, TCE: 'It places the individual at the heart of its activities, by establishing the citizenship of the Union and by creating an area of freedom, security and justice.'

128 [2000] OJ L 317/43.

129 Athens Declaration made at the Athens Informal European Council, 16 April 2003, [2003] OJ L 236, available at: http://www.eu2003.gr/en/articles/2003/4/16/2531/index.asp?. 


\section{B. Two Critiques}

These recent developments have been heavily criticised from a human rights perspective. It is primarily the hiatus between the lack of extensive internal human rights policy and proactive external actions in the field of human rights protection that disturbs most observers. For instance, many Copenhagen criteria for accession by new Member States are hardly respected by some of the current Member States. It is therefore only by seeing the internal dimension of the Union's human rights policy as cut from the same cloth as its external dimension that the latter can be truly successful and that the EU can avoid using doublestandards. ${ }^{130}$ According to Alston and Weiler's famous 1999 report, 'the Union can only achieve the leadership role to which it aspires through the example its sets to its partners and other States. Leading by example should become the leitmotiv of a new EU human rights policy ..... ${ }^{131}$

Another critique pertains to the lack of clear competence of the EU in the field of human rights, both internally and externally. It is indeed a consequence of the origins of the EU human rights regime that it is rather defensive and neutral, and is meant to reinforce national competences in the area rather than curtail them or give them new directions. Even the latest constitutionalised version of the Charter reiterates in Article II-111 that it does not create a new EU competence in the human rights field ${ }^{132}$ and that the Charter's rights ought to be interpreted in conformity with the ECHR and national constitutions' rights in Article II-112. This is also reiterated in Article I-9 of the TCE. In fact, the idea of the Charter originated in Member States. It was not meant to extend existing guarantees, but rather to delineate them more carefully and place them in the service of national ones. ${ }^{133}$ To date, therefore, it is not clear whether the EU has a real competence in the field of human rights.

\section{Evidence of Transformation}

All this does not, however, preclude the possibility of progress and institutional reform. In fact, recent developments are evidence of the transformation of the EU into a post-national human rights institution, that is to say one with human rights at the core of its institutional framework, or at least evidence of this potential transformation. Besides general evidence, I will also present the development of European citizenship as a signal of the emancipation of human rights protection in the EU.

130 See Williams, supra n. 12 at 85.

131 Alston and Weiler, supra n. 12 at 21-3.

132 On the case law that is at the origin of Article II-111, TCE, see Jacobs, supra n. 7.

133 See von Bogdandy, supra n. 2. 


\section{(i) General}

Evidence of a change in fundamental rights' jurisdiction in the EU flows indiscriminately from both internal and external elements in EU human rights policies. First of all, the Charter's denial of a new competence in the field of human rights in Article II-111 is belied by the mention of positive duties of Member States in the same Article. It is now widely accepted that human rights do not only give rise to negative duties, but also to positive duties to make sure these negative duties are respected. This applies, of course, to the EU, but also to Member States when they apply or derogate from EC law. Thus, if EU institutions can be held accountable to the EU for failing to respect their positive duties of promoting the rights in the Charter (Article 51(1)), the EU's rule-making power has been extended in the field. ${ }^{134}$

Secondly, the scope ratione materiae of Articles 6 and 7 of the Amsterdam Treaty is not clearly restricted to the application of EC law. This is exemplified by the scope of analysis of the Independent Network of Experts established by the European Commission in 2002 and which monitors human rights protection in purely internal situations in Member States. ${ }^{135}$ This trend has been confirmed recently with the Commission's proposal for a Council Regulation establishing a European Union Agency for Fundamental Rights whose scope of action can, under certain conditions, go beyond the areas of application of EC law. ${ }^{136}$ A third argument may be drawn from the fact that some of the rights guaranteed by the Charter are rights which would never find application within the material scope of EC law, such as the right to life or the right to education. ${ }^{137}$

Finally, fundamental rights jurisdiction in the EU has recently been extended to those decisions taken by Member States in the framework of other international organisations and which affect their fundamental duties under EU law. This was exemplified in particular by the Court of First Instance's decision in the Kadi and Yusuf cases, in which it grants itself the competence to check United Nations Security Council resolutions for respect of jus cogens. ${ }^{138}$ Although the consequences of these cases are difficult to assess with precision, and an appeal to the ECJ is currently pending, it clearly opens a new scope for fundamental rights scrutiny in the EU.

134 See Eeckhout, supra n. 7 at 980 and 993.

135 On the network, see: http://www.europa.eu.int/comm/justicehome/cfr_cdf/index_en.htm.

$136 \operatorname{COM}(2005) 280$ final. See, for different aspects of the Agency, Alston and de Schutter, supra n. 4 .

137 See Eeckhout, supra n. 7 at 952.

138 T-315/01, Kadi v Council and Commission [2005] ECR II-0000; and T-306/01, Yusuf and Al Barakaat International v Council [2005] ECR II-0000. 
(ii) The relationship between human rights protection and EU citizenship

A further hint of development may be found in the close relationship between EU citizenship and human rights. Human rights and citizenship rights are usually invoked as the two prongs of an irreconcilable point of tension between the universalising human rights discourse and the particular, exclusive status of political membership. ${ }^{139}$ The recent evolution of EU citizenship shows, however, how post-national citizenship may evolve towards a more inclusive form of political membership that is in line with human rights guarantees, both in terms of its personal and material scope. This also demonstrates, I will argue, how EU citizenship, in return, can help the EU human rights regime become more universal and apply across the board in the EU and its Member States outside the material scope of the EC Treaty and beyond the economic limits of European integration (see, for example, Article 52(2) of the Charter).

Intrinsically related to the democratic ideal, the concept and regime of EU citizenship was introduced by Articles 8 et seq. of the Maastricht Treaty to palliate the democratic deficit of the EU. It was then slightly revised by Articles 17-21 of the Amsterdam Treaty, to reassure Member States and to emphasise that EU citizenship does not replace national citizenship. According to Article 17(1) of the ECT, 'every person holding the nationality of a Member State shall be a citizen of the Union. Citizenship of the Union shall complement and not replace national citizenship.' Thus, EU citizenship depends on Member State nationality. Since the conferral and withdrawal of Member State nationality remain for each Member State to decide, ${ }^{140}$ this greatly limits the potential impact of EU citizenship. Further, Union citizenship does not replace national citizenship. EU citizenship should not therefore be confused with a European form of nationality and is therefore conceptually uncoupled from nationality, and should not be associated with a pan-European form of nationalism.

Article 17(2) of the ECT identifies EU citizenship with a legal relationship between the EU and Member State nationals to which are attached specific rights and duties. These correspond to all the rights and duties which already derive from the Treaty and secondary legislation. As such, Articles 18-21 of the ECT can be equated to a standstill clause that prevents the erosion of the acquis communautaire. It also follows, however, that EU citizenship is evolutionary and can expand to new rights together with the expansion of the scope of the EC Treaty. The list of rights attached to EU citizenship in Articles 18-21 mostly recapitulates pre-existing rights, with the exception of the new political rights in Articles 19 and 20. It is therefore quite piecemeal; it does not match lists

139 See Benhabib, The Rights of Others. Aliens, Residents and Citizens (Cambridge: Cambridge University Press, 2004) at Chapter 4.

140 This was confirmed recently by the ECJ in C-200/02, Kunqian Catherine Zhu, Man Lavette Chen v Secretary of State for the Home Department [2004] ECR I-9923. 
of national citizenship rights and is particularly thin in terms of political rights. The citizenship rights expressly protected are the right of free movement and residence within the territory of any Member State; the right to vote and stand as a candidate at municipal elections and in elections to the European Parliament in the Member State in which the citizen resides; the right to diplomatic and consular protection by any Member State's authorities in third countries; and the right to petition the European Parliament and to apply to the European Ombudsman. Most recently, the Charter has largely reiterated these rights, but has also brought in a few new rights from the EC Treaty, splitting some rights in two and extending the scope ratione personae of most rights except political rights, in order to encompass third-country nationals residing in the EU. Finally, the TCE guarantees EU citizenship rights through the constitutionalised Charter in Articles II-99 to 102 of the TCE and, in a shorter form, in Article I-10 of the TCE. ${ }^{141}$

At first, European citizenship was heavily criticised as an empty promise or pure rhetoric, and as an exercise in window-dressing of the underlying market citizenship. In the meantime, and thanks to important jurisprudential developments, EU citizenship has become a key element of the new European polity which has a huge potential for the legitimacy of the global institutional order. $^{142}$ Thanks to the emancipation of EU citizenship, the material scope of application of EU citizenship rights and the personal scope of EU citizenship rights-bearers are indeed constantly expanding within the territory of the EU, but also, as a consequence, outside the EU.

There was, for a long time, growing concern at the market-oriented nature of EU citizenship and the material scope of application of citizens' rights in the EU. In principle, citizenship amounts to membership of a political community. As we have just seen, however, most EU citizenship rights are economic rights attached to migrant workers, thus excluding many Member State nationals residing in the EU and turning them into second-class citizens. Over the past five years or so, the ECJ has developed the social elements of EU citizenship, thus making it a source of rights of its own. ${ }^{143}$ This evolution has taken place primarily through

141 The following presentation focuses on the regime currently in force and does not refer to the new constitutional dispositions.

142 See Shaw, 'The Many Pasts and Futures of Citizenship in the European Union', (1997) 22 European Law Review 554; and Weiler, The Constitution of Europe: 'Do The New Clothes Have An Emperor?', and Other Essays on European Integration (Cambridge: Cambridge University Press, 1999) at 324 et seq.

143 See Eeckhout, supra n. 7; and O'Leary, 'The Relation between Community Citizenship and Fundamental Rights', (1995) 32 Common Market Law Review 519. See also Advocate General Jacobs in C-168/91 Konstantinidis v Stadt Altensteig Standesamt [1993] ECR I-1991 at para 46 :

In my opinion, a Community national who goes to another Member State as a worker or self-employed person under Articles 48, 52 or 59 of the Treaty is entitled not just to 
the combined reading of EU citizenship and anti-discrimination provisions, and in particular of Article 18 of the ECT's freedom of movement and residence and Article 12 of the ECT's prohibition of discrimination on grounds of nationality. Through this connection, the case law finally expanded EU citizenship by making it the fundamental status from which citizens may directly derive individual rights, while also providing a more universal scope for protection against discrimination in EC law. Until recently, for Article 12 to apply, one needed to show that the issue at stake fell into the scope of application of the Treaty. This implied falling into the scope ratione materiae of EC law and required some involvement in an economic activity as a worker. Recent case law has changed this and no longer restricts the respect of EU citizenship to the scope ratione materiae of EC law. ${ }^{144}$

Another area of concern has been the status of third-country nationals in the EU and their political exclusion. Their political rights remain generally unrecognised with the exception of a few European countries. Since European others, such as, for instance, German nationals in France or vice-versa, may, as European citizens, take part in municipal and European elections in other Member States, it is difficult to see why non-European others legally residing in the EU could not benefit from the same rights. The solution is therefore either to extend political rights of EU citizenship to third-country nationals residing in the EU or to redefine EU citizenship as based on residence and not on nationality. The latter approach would clearly be rejected by Member States who fear for their national prerogatives. In any case, the recent tendency in the case law and legislation seems to be the former, if one refers to the extension of the scope of application ratione personae of some EU citizenship rights guaranteed in the Charter (Articles 41-45), with, however, the exception so far of political rights. This also seems to follow from the recent harmonisation of third-country nationals' residence rights in the EU. ${ }^{145}$ The difficulty with this

pursue his trade or profession and to enjoy the same living and working conditions as nationals of the host State; he is in addition entitled to assume that [...] he will be treated in accordance with a common code of fundamental values [...]. In other words, he is entitled to say 'civis europeus sum' and to invoke that status in order to oppose any violation of his fundamental rights.

144 See C-85/96, Maria Martinez Sala v Freistaat Bayern [1998] ECR I-2691; C-184/99, Grzelczyk v Centre Public d'Aide Sociale d'Ottignes-Louvain-la-Neuve [2001] ECR I-6193; C-413/99, Baumbast v Secretary of State for the Home Department [2002] ECR I-7091; and C-60/00, Mary Carpenter $v$ Secretary of State for the Home Department [2002] ECR I-6279. See also C-138/02, Brian Francis Collins v Secretary of State for Work and Pensions [2004] ECR I-2703 C-456/02, Trojani v Centre publique d'aide sociale de Bruxelles [2004] ECR I-7573; and C-200/02, Kunqian Catherine Zhu, Man Lavette Chen v Secretary of State for the Home Department, supra n. 140.

145 See Directive 2004/38/EC on the right of citizens of the Union and their family members to move and reside freely within the territory of the Member States, [2004] OJ L 158/77, and Directive 2003/109/EC concerning the status of third-country nationals who are long-term residents, [2004] OJ L 16/44. 
approach is that it risks diluting the idea of political membership and the exclusivity of rights citizenship guarantees, on the one hand, and creating second-class citizens, on the other. A more inclusive and 'bottom to top' alternative might be to encourage Member States to facilitate the naturalisation of third-country nationals residing on their territory and thus to extend the EU political franchise. This actually corresponds to a recent tendency emerging in certain Member States where foreigners' political rights are gradually being extended.

To sum up, EU citizenship is gradually emancipating its scope ratione materiae from a purely legalistic and market-based conception of citizenship, and in its scope ratione personae from an exclusive conception of post-national political membership. Its recent evolution has shown how post-national citizenship has turned into a more inclusive form of social and political membership that is in line with universal human rights guarantees. Accordingly, one may legitimately hope that EU citizenship can in return help the EU human rights regime to become more universal in scope. If antidiscrimination rights have helped extend the scope ratione materiae of European citizenship, the latter may in return, as Eeckhout argues, help extend the scope ratione materiae of EU fundamental rights in general. These fundamental rights are still characterised by an economic emphasis and the limits set by the EC Treaty. Thanks to the extension of their material scope, they could be made to encompass any situation in which a European citizen sees her rights violated, be it by the EU or a Member State, and whether this takes place in the context of the application of EC law or not. ${ }^{146}$

\section{Towards A Post-National Human Rights Institution}

If there is evidence of a transformation of the EU into a post-national human rights institution, it cannot replace more persuasive arguments for the transformation and development of a true human rights competence of the EU merely because it already appears to have taken place. To provide such arguments, I will start by making an argument for the EU's capacity in the area based on the specificities of its human rights agency and by reference to the institutional design criteria I have developed earlier. I will then address different critiques, before finally making a few proposals for reform.

\section{A. The Specificities of Human Rights Agency in the EU}

To make an argument for the EU's capacity as a post-national human rights institution, it is important to start with an argument for its role as 
a global justice agent. Then we will look into its more specific potential as a human rights agent.

(i) The EU as a global justice agent

In a nutshell, there are three arguments one can make for the EU's specific capacity to contribute to a new justice order. ${ }^{147}$

First of all, the EU's complex institutional structure and modes of cooperation make it the most institutionally dense environment in the international system. There are three main bearers of global justice responsibilities in the EU. First of all, there is the EU polity itself, as a primary agent of justice through its organs and inner institutions, such as the ECJ, the Council (of Ministers), the Parliament and the Commission (albeit the latter not in a direct way in terms of sanctions, but, for example, rather as an initiator for various democratic and communicative processes and policies to draw attention to human right issues within and outside the EU). There are the Member States, which can play different roles as agents of European justice in domestic or European affairs. The European model of competence allocation is complex and Member States can be called upon to act on their own or together with the EU. Finally, non-State agents as groups of individuals like NGOs, but also other kinds of social and economic organisations like trade unions, can act as human rights protectors.

Secondly, the EU's miniaturised world helps it to crystallise and find solutions to global problems within the EU. The EU has indeed managed to create a just order among States without assuming away the plural nature of its polity and its peoples. As such, the EU encourages State-like solidarity in a post-national polity, thus creating the basis for a true global justice political order. ${ }^{148}$ This in turn gives it a comparative advantage in shaping challenges at the global level. Finally, not only does the EU have the institutional framework and political know-how to promote a shift in the global agenda, but it has the credibility among international actors to play such a role. This is of course due to its crucial economic weight. However, its role as a civilian power in development assistance and peace-building has also contributed to increasing the EU's global presence.

(ii) The EU as a human rights agent

To assess the EU's capacity to become a post-national human rights institution, it is important to go further and examine whether the EU's institutional organisation matches the criteria that were defined in the above discussion of 
the design of human rights institutions. Not only does the EU fulfil them, but it is characterised by specificities which make it a particularly potent institution in the human rights protection context. As I explained before, institutional design and evolution usually match new normative needs and this is clearly the case in the human rights field, where new instruments are called for to meet global challenges. The EU's institutional specificities make it a particularly able institutional framework to deal with the diversity of conceptions of human rights in Europe; they give it a clear comparative advantage to other European human rights organisations such as the Council of Europe or the Organisation for Security and Cooperation in Europe. ${ }^{149}$

With respect to the internal organisation of the EU qua a post-national human rights institution, it is clear that it differs from other similar institutions. The EU is a multi-layered institution that encompasses, within the same political and legal order lato sensu, its Member States' internal institutions and European internal institutions stricto sensu. Thus, human rights mechanisms apply not only to national situations like other international human rights instruments, but also to EU policies and actions. ${ }^{150}$ Additionally, the EU's internal organisation combines the scrutiny of legislative, executive and judicial powers and cannot be reduced to the ECJ and judicial human rights scrutiny. This enables the EU to have recourse to human rights enforcement mechanisms other than judicial remedies, such as policy-making, mainstreaming ${ }^{151}$ or monitoring. ${ }^{152}$ This is clearly the case of the proposed EU Fundamental Rights Agency whose mandate will be to promote human rights compliance through political means. Moreover, even within its judicial scrutiny powers, the EU uniquely combines different layers of judicial control. National courts, the ECJ and the ECtHR all apply at least some of the same human rights, within almost the same material scope of application and over the same territory. ${ }^{153}$ This confirms the common image of a 'human rights laboratory' to which some authors have been referring. ${ }^{154}$ The EU's accession to the ECHR could only improve this cooperative relationship

149 See Williams, supra n. 12 at $77-8$.

150 Eeckhout, supra n. 7 at 990.

151 See de Schutter, 'Mainstreaming Fundamental Rights in the EU', in Alston and de Schutter (eds), supra n. 4 at Chapter 2.

152 See Alston and Weiler, supra n. 12 at 13. See also the essays in Alston and de Schutter, supra n. 4 and, in particular, Chapter 1: de Burca, “New Modes of Governance” and the Implementation of Fundamental Rights'.

153 On the complexity of the relationships between these different jurisdictional layers, see Dutheil de la Rochère, 'Droits de l'homme: La Charte des droits fondamentaux et au-delà, Jean Monnet Working Paper 10/2001; and McCrudden, 'The Future of the EU Charter of Fundamental Rights', Jean Monnet Working Paper 10/2001.

154 See, for example, Weiler, 'In Defence of the Status Quo: Europe's Constitutional Sonderweg', in Weiler and Wind (eds), supra n. 17, 7; and Pernice and Kanitz, 'Fundamental Rights and Multi-level Constitutionalism in Europe', WHI Paper 7/04, available at: http://www.rewi.huberlin.de/WHI/english. 
among human rights jurisdictions in Europe. ${ }^{155}$ This multi-level and cooperative model of constitutional jurisdiction provides an exceptional jurisprudential basis that other human rights organisations have lacked so far. ${ }^{156}$ It suffices to refer to the recent case law of the ECJ, national supreme courts and the ECtHR to realise the unique dialogue and cooperation they have generated. ${ }^{157}$

Secondly, as to the existence of a core competence in human rights protection among other EU competences, we have seen before how the emergence of a true competence underlying human rights policies and monitoring may be observed in the EU. This has enabled the EU to start monitoring human rights protection in purely national areas, for instance. ${ }^{158}$ It is important to emphasise, however, that the emergence of such a competence need not imply that human rights should be seen as a discrete and coherent area of European law; human rights apply across different areas and need not be administered by a centralised and specific human rights administration, contrary to von Bogdandy's critique. ${ }^{159}$

If a human rights institution like the $\mathrm{EU}$ is to be deemed a post-national human rights institution, a third criterion needs to be added that makes its post-national dimension specific: its global know-how. The EU occupies a unique and powerful position in international affairs, thanks in particular to its economic resources, that would help it deploy an effective human rights policy. ${ }^{160}$ The fact that the EU is the largest donor of aid to the South and the East and has a massive market capacity ensures that developing countries feel pressured to abide by the human rights standards it establishes. Moreover, through its aspiration to represent the peoples of Europe, the EU has traditionally maintained a political perspective that is as external as internal, and cannot therefore be accused of isolationism. ${ }^{161}$ Since institutional arrangements and the related responsibilities in the EU have first been concentrated at the transnational level, thus transcending the traditional transnational duties of their Member States, the next step, shifting them one rung up the ladder of the global institutional framework in Member States' relationship to third countries, seems almost natural. The externalisation of duties of justice from the realm of a single polity to a multi-polity is already at play within the EU itself ${ }^{162}$ and

155 See Bribosia, 'La future Constitution: point culminant de la constitutionnalisation des droits fondamentaux dans l'Union européenne', in Magnette (ed.), La Grande Europe (Brussels: Editions de l'Université de Bruxelles, 2004) 201; and Lawson, supra n. 9.

156 See Williams, supra n. 12 at 79.

157 See, for example, Bosphorus Hava Yollari Turizm ve Ticaret Anonim Sirketi v Ireland (2006) 42 EHRR 1; and BVerfGE, Gorgülu, BVerfGE, 2 BvR 1481/04 (2004).

158 See Alston and de Schutter, supra n. 4 at 5-6.

159 von Bogdandy, supra n. 2 at 1311-2.

160 See Williams, supra n. 12 at 78.

161 Ibid. at 78-9.

162 See Habermas and Derrida, 'What Binds Europeans Together: A Plea For A Common Foreign Policy, Beginning in the Core of Europe', (2003) 10 Constellations 291. 
this should increase the ability of the EU to promote human rights on the outside as much as on the inside.

A fourth criterion in the design of post-national human rights institutions is their publicity and transparency. Here too the EU presents specific qualities. The EU offers important dialogical possibilities and its concern for public debate, consultation, polls and transparency suggests it has the qualities ideally required of a global justice framework. ${ }^{163}$ A final criterion that is related to the previous one is democracy. The EU's democratic regime, even if it is still imperfect, distinguishes the EU from other international institutional regimes and makes it particularly adept for its human rights protection function. Due to the EU's legitimacy crisis and its alleged democratic deficit, different measures have been taken to improve the situation since the early 1990s, culminating in the Constitutional Treaty's chapter on democracy and other measures of promotion of deliberation in the EU. In comparison with other human rights institutions, the multi-layered and multi-faceted governance in the EU offers greater channels of democratic accountability. For instance, the tensions between the visions of the EU's mandate in human rights issues between the Commission, the Parliament and the ECJ have been productive over the years $^{164}$ and have no doubt led to recent breakthroughs in the area.

\section{B. Some Critiques}

Of course, one may doubt the ability of a primarily economic organisation to turn into a human rights institution overnight. Different critiques have been put forward, not always successfully, and it is important to address them in turn.

First of all, one should mention the critique that the EU does not have the judicial apparatus it takes to protect human rights efficiently. ${ }^{165}$ This concern relates both to the legal reasoning method, the level of scrutiny and the locus standi in cases of human rights violation, and hence to the effectivity of judicial human rights protection in the EU. Regarding the effectivity of judicial control, one should, however, mention the guarantee in Article 47 of the Charter to the right to an effective judicial remedy, and the new Article III-365 of the TCE's extension of the locus standi in the action for annulment. ${ }^{166}$ True, these few improvements made by the Constitutional Treaty to locus standi in human rights matters remain limited. However, human rights have recently become as central to the ECJ's case law as basic freedoms case law; there is no longer any difference in quality between the two kinds of liberties in terms of scrutiny. ${ }^{167}$

163 See Williams, supra n. 12 at $77-8$.

164 See, for example, Eeckhout, supra n. 7.

165 See, for example, Coppel/O’Neill, supra n. 119; and De Witte, 'The Past and Future Role of the ECJ in the Protection of Human Rights', in Alston et al. (eds), The EU and Human Rights (Oxford: Oxford University Press, 1999) 859.

166 See Lawson, supra n. 9 at 29; and Bribosia, supra n. 155 at 208-10.

167 See, for example, C-112/00, Schmidberger v Austria [2003] ECR I-5659. 
Moreover, the full picture of fundamental rights protection in Europe cannot be reduced to judicial protection in the EU. National courts', the ECJ's and the ECtHR's decisions should all be assessed together as key components of the post-national judicial protection of fundamental rights in Europe. Finally, judicial protection is not the only way in which human rights may be protected at the post-national level, contrary to what the traditional liberal conception of human rights holds.

Secondly, the EU's non-judicial institutions are allegedly not sufficiently autonomous from Member States' governments. In this sense, EU human rights protection could not compare in independence with Member States' protection in terms of local assessment and interpretation. It would necessarily reflect the opinion and interests of a majority of Member States at the detriment of minorities in Europe. ${ }^{168}$ This might even contribute, according to some authors, to transposing a neo-colonial way of thinking about European interventions to the South and the East. ${ }^{169}$ Although it is true that Member States were the first to demand human rights protection in the EU, human rights scrutiny in the EU has quickly overcome the tight boundaries they had set for it, despite some Member States' recent efforts during the drafting process of the Charter. ${ }^{170}$ As we saw before, for instance, human rights monitoring through some EU agencies applies even in areas of strict national competence.

A third connected concern is the EU's lack of independence from the economic and corporate world. There is a paradox indeed in the reinforcement of the EU's ability to promote a human rights policy through its economic power. While it is easy to understand how economic credibility can enhance persuasion power, it may also pervert human rights in submitting them to economic interests and an economically driven balance of interests. ${ }^{171}$ The delicate balance between internal and external measures of human rights protection has contributed, however, to strengthen human rights arguments against economic interests. One may notice this, for instance, in the context of anti-discrimination protection or of citizenship rights. This is exemplified at best by the recent ECJ case law on conflicts between fundamental (economic) freedoms and fundamental rights where fundamental rights are equal in the balance and gradually take precedence. ${ }^{172}$ Moreover, it is crucial to understand that the failure and contestation of traditional human rights organisations have made it necessary to adopt a more adventurous stance towards future institutional frameworks of global human rights protection. ${ }^{173}$

168 See Williams, supra n. 12 at 79.

169 Ibid. at 80.

170 The 2000 Charter Convention's President was Roman Herzog and his views regarding German constitutional sovereignty were well-known.

171 See Williams, supra n. 12 at 79.

172 Recent examples are Schmidberger $v$ Austria, supra n. 167 and C-36/02, Omega $v$ Oberbürgermeisterin der Bundesstadt Bonn [2004] ECR I-9609.

173 See Williams, supra n. 12 at 86. 
A fourth objection relates to subsidiarity and the delicate balance between Member States and the EU. According to von Bogdandy, the transformation of the EU into a human rights institution would lead to the Europeanisation of human rights competence and a uniformisation of human rights standards in the EU which would disempower those very national authorities and standards which are closer to fundamental rights violations and are hence in a better position to judge them. ${ }^{174}$ At the moment, however, whenever there is an EU competence, the allocation of duties of justice in the EU follows a complex principle of subsidiarity that underlies a new model of cooperative sovereignty in a post-national polity. ${ }^{175}$ The principle of subsidiarity was introduced in European law by Article 5(2) of the ECT. It has recently been consolidated in the TCE (Article I-11 of the TCE) and an Additional Protocol on sovereignty, which foresees different implementation mechanisms. ${ }^{176}$ It constitutes one of the key principles of the division of competences in the EU; in the absence of exclusive competence, European authorities can only take action when the objectives of the proposed action cannot be satisfactorily attained by Member States, and therefore have a better chance of being achieved by the Community. ${ }^{177}$ Accordingly, the bearers of duties in the EU are those who best respect the human rights at stake in each concrete case in the whole territory of the Union. Therefore, it is important to make sure that the transformation of the EU into a human rights institution does not undermine, but, on the contrary makes the most of, subsidiarity. ${ }^{178}$ This is characterised by the multi-level network of institutions and the so-called human rights laboratory ${ }^{179}$ we are experimenting with in the EU: where national courts, the ECJ and the ECtHR contribute to the application of the same rights in Europe. This is very important if one is to preserve diversity on controversial issues of values in Europe. ${ }^{180}$

174 von Bogdandy, supra n. 2 at 1316-8.

175 See Besson, 'Sovereignty in Conflict', (2004) 8 European Integration On-line Papers, available at: http://eiop.or.at/eiop/texte/2004-015a.htm; and Besson, 'The Taming of Sovereignty. A Review of Neil Walker's Sovereignty in Transition', (2005) 3 International Journal of Constitutional Law 147.

176 Follesdal, 'Subsidiarity, Democracy, and Human Rights in the Constitutional Treaty of Europe', (2006) 37 Journal of Social Philosophy 61.

177 Despite the addition of the Subsidiarity Protocol to the Amsterdam Treaty and its consolidation in the Constitutional Treaty (Article I-11), the principle has not yet had the impact it deserves at EU level. See, for example, Estella, The EU Principle of Subsidiarity and Its Critiques (Oxford: Oxford University Press, 2002) at 6-7.

178 Compare von Bogdandy, supra n. 2 at 1319 who does not seem to think this is possible, but whose proposal of a three-layered human rights protection system does not exclude subsidiarity concerns in the third layer of human rights that includes EC institutions and Member States when they apply EC law.

179 Pernice and Kanitz, supra n. 154.

180 See, for example, Keller and Bertschi, 'Erfolgspotenzial des 14. Protokolls zur Europäischen Menschenrechtskonvention', [2005] Europäische Grundrechtszeitschrift 204; and Müller, 'Koordination der Grundrechtsschutzes in Europa-Einleitungsreferat', [2005] Revue de droit suisse 9. 
Of course, constitutional conflicts can always occur among these different levels of human rights protection. ${ }^{181}$ The European principle of coherence constitutes, however, an interesting means to preserve a certain amount of unity and continuity in diversity when these conflicts occur. ${ }^{182}$

Finally, the EU's intervention in the human rights field might threaten the work of other human rights organisations like the UN or the Council of Europe. ${ }^{183}$ Although these international organisations are not flawless, they have made a significant contribution to the advancement of human rights since the Second World War. The emancipation of the EU in the human rights context need not, however, imply the end of other institutions' impact on human rights protection in Europe. On the contrary, the competition and cooperation of all institutions when they deal with the application of the same human rights over the same territory and population ensure an enhanced protection of these rights. It is important, however, to make sure European mainstreaming of fundamental rights takes other instruments and institutions sufficiently into account. ${ }^{184}$ Moreover, subsidiarity and respect for mutual competence should be a guiding value, thus avoiding overloading certain jurisdictions with competences of control they do not have. The recent ECtHR decision in the Bosphorus case goes in that direction vis-à-vis the ECJ, ${ }^{185}$ but other decisions are also noteworthy such as the Court of First Instance's decision in the Kadi and Yusuf cases, in which that Court grants itself the competence to review UN Security Council resolutions on the basis of jus cogens. ${ }^{186}$ In any case, human rights need not be seen as sufficiently protected by existing regional and global institutions. There is, in fact, growing concern over the effectiveness of traditional human rights institutions vis-à-vis new actors and in new multi-layered settings, as exemplified by the ECtHR's backlog. This might explain the renewed interest in the EU's unique and complementary institutional specificities in this respect. ${ }^{187}$

\section{Scope for Reform}

In view of these critiques, and despite their many shortcomings, it is important to emphasise that the EU should transform itself even further if it is to become a truly post-national human rights institution. Its human rights protection

181 See, for example, Spielmann, 'Human Rights Case Law in the Strasbourg and Luxembourg Courts: Inconsistencies and Complementarities', in Alston et al. (eds) supra n. 165, 758.

182 See Besson, 'From European Integration to European Integrity. Should European Law Speak With Just One Voice?', (2004) 10 European Law Journal 257.

183 See Williams, supra n. 12 at 80.

184 See de Schutter, supra n. 151 at Chapter 2.

185 Bosphorus Hava Yollari Turizm ve Ticaret Anonim Sirketi v Ireland, supra n. 157.

186 Kadi v Council and Commission, supra n. 138.

187 Williams, supra n. 12 at 86. 
function is still in development, as exemplified by the current debates on the constitutionalisation of the Charter and the implications of the constitutionalised Charter. ${ }^{188}$

According to Williams, one of the first things the EU should improve, to enhance its capacity of transformation into a human rights protection institution, is its ability to conceptualise human rights independently from its Member States. ${ }^{189}$ This need not, however, lead to the uniformisation of a European human rights conception, as many authors like Weiler fear it might, ${ }^{190}$ but rather to a levelling-up of national ones. This could be done, for instance, through comparative constitutional law and judicial coherence across the EU. ${ }^{191}$ In fact, this transformation is already taking place and one Member State's level of protection of human rights may from now on be taken as the standard of the EU's human rights protection, even though it is higher than that of other Member States. ${ }^{192}$ Here lies the specific strength of the EU human rights regime. It results, thanks to the principle of subsidiarity, from a dialectic between EU guarantees and national traditions, and thus avoids both the impoverishment of international unified guarantees and the parochialism of diverse national ones.

Another area of necessary reform, now that EU competence in the human rights field is becoming more precise, despite the absence of express competence attribution, is the coherence one should aim at observing between human rights protection outside the EU and internal levels of protection. ${ }^{193}$ An important dimension of reform lies therefore in putting European internal and external responsibilities in line with one another and hence addressing what Alston and Weiler have referred to as 'the element of schizophrenia that afflicts the Union between its internal and external policies. ${ }^{194}$ This applies as much to the failures of internal policies compared with those of external policies as to the reverse. Indeed, authors often concentrate on the gaps in internal policies

188 See, for example, Lawson, supra n. 9; and Dutheil de la Rochère, supra n. 4.

189 Williams, supra n. 12 at $81-4$.

190 See, for example, Weiler, 'Fundamental Rights and Fundamental Boundaries', in Neuwahl and Rosas (eds), The European Union and Human Rights (Dordrecht: Kluwer, 1995) 51. See also Besselink, 'Entrapped by the Maximum Standard: On Fundamental Rights, Pluralism and Subsidiarity in the European Union', (1998) 35 Common Market Law Review 629; and Besselink, 'The Member States, the National Constitutions and the Scope of the Charter', (2001) Maastricht Journal of European Law 68.

191 On the principle of coherence in European law, see Besson, supra n. 182.

192 See Omega v Oberbürgermeisterin der Bundesstadt Bonn, supra n. 172. See also Besson and Pfersmann, 'Lautorité du droit constitutionnel comparé dans l'UE', (2007) Revue internationale de droit comparé [forthcoming] on the method and justification of comparative constitutional law in the EU.

193 Williams, supra n. 12 at 85.

194 Alston and Weiler, supra n. 12 at 9. 
when compared with external ones, but sometimes external measures may have to be adapted to more advanced internal ones. ${ }^{195}$

\section{Conclusion}

Five years ago, von Bogdandy provocatively raised the question whether the EU was or could be what he referred to as a 'human rights organisation'. Since then, countless arguments in favour of the EU developing into a global or post-national human rights 'organisation', 'regime' or 'framework' have been brought forward. Most of them rely on recent evidence of this transformation both in internal and external European policies. They leave open, however, what should be understood by a 'human rights organisation' and why the EU's transformation into this new kind of post-national human rights protection institution should be deemed as valuable in the first place.

Based on global justice theories and a matching account of post-national institutional design and also on essential insights into human rights theory, this article has hopefully helped clarify the contours of what can be expected to a post-national human rights organisation. On those grounds, it also aimed to emphasise the unique capacity of the EU in that respect and the scope of the human rights duties it now bears. True, numerous shortcomings may still be identified with the EU's prima facie economic take on human rights. The article identified many of them, and made different proposals for reform to enhance the EU's unique capacity for human rights protection in Europe. Thus, not only is the best yet to come, but the best ought actually to be coming in terms of human rights protection in the EU.

195 Interestingly, for instance, while the degree of internal fundamental rights protection is inferior to that of external fundamental rights protection, European citizenship rights are better protected in the EU than the political rights of third-country nationals in EU Member States. 